\begin{tabular}{|c|c|}
\hline \multicolumn{2}{|r|}{ About the Journal } \\
\hline Journal DOI & https://doi.org/10.21659/rupkatha \\
\hline Journal Home & www.rupkatha.com \\
\hline Indexed by & Scopus $\boldsymbol{\nearrow}$ Web of Science: Emerging Sources Citation Index (ESCI) DOAJ \\
\hline Journal Metrics & CiteScore 2020: 0.2 | SJR 2020: 0.162 | SNIP 2020: 0.193 | JCI 2020: 0.50 \\
\hline \multicolumn{2}{|r|}{ About the Issue } \\
\hline Themed issue & $\begin{array}{l}\text { Volume 4, number 1, } 2022 \text { (January-March) | Contemporary East and } \\
\text { Southeast Asian Literary and Cultural Studies }\end{array}$ \\
\hline Guest Editors & Dr Jeremy de Chavez $\oslash \&$ Dr Zhang Yue, University of Macau, China \\
\hline Issue DOI & https://doi.org/10.21659/rupkatha.v14n1 \\
\hline TOC & https://rupkatha.com/v14n1.php $~$ \\
\hline Peer Review & Under the responsibility of the Guest Editors \\
\hline \multicolumn{2}{|r|}{ About the Article } \\
\hline Title & $\begin{array}{l}\text { Introduction to Antiquarian Chinese Book Collections in Contemporary } \\
\text { Macao }\end{array}$ \\
\hline Author/s & Chon Chit TANG $\bowtie$ \\
\hline Affiliation & University of Macau, China. \\
\hline Funding & No funding received. Published free of any charge. \\
\hline Article DOI & https://doi.org/10.21659/rupkatha.v14n1.06 Pages: 1-5 \\
\hline Abstract & https://rupkatha.com/v14n106 \\
\hline Full-text PDF & https://rupkatha.com/V14/n1/v14n106.pdf $入$ \\
\hline \multirow[t]{3}{*}{ Article History } & Abstract received: 31 March 2021 | Complete article received: 6 June 2021 \\
\hline & Accepted: 30 August 2021 \\
\hline & First Published: 05 February 2022 \\
\hline Article Impact & Check Dynamic Impact $\oslash$ \\
\hline Copyright & Aesthetics Media Services $\square$ \\
\hline Licensing & Creative Commons Attribution Non-Commercial 4.0 \\
\hline
\end{tabular}

This Open Access article is published under a Creative Commons Attribution Non-Commercial 4.0 International License (http://creativecommons.org/licenses/by-nc/4.0/), which permits non-commercial re-use, distribution, and reproduction in any medium, provided the original work is properly cited. For citation use the DOI. For commercial re-use, please contact editor@rupkatha.com. 
1 Rupkatha Journal, Vol. 14, No. 1, 2022

Research Article

\title{
Introduction to Antiquarian Chinese Book Collections in Contemporary Macao
}

\author{
Chon Chit TANG \\ University of Macau, China.
}

\begin{abstract}
This essay briefly discusses the historical development of the society of Macao, the book collection systems and categories adopted within Macao, major characteristics of antiquarian Chinese books in Macao, and theirrelationship with the culture of Macao.
\end{abstract}

Keywords: antiquarian Chinese book collections, social culture, Macao

As early as the Shang and Zhou Dynasties (ca. 1600-256 BCE), collections of antiquarian documents functioned as important vehicles for the transmission of knowledge and recording of achievements of civilization in ancient China. Meanwhile, translations and other writings became critical media for the importation and dissemination of foreign cultures. The Chinese used paper 1000 years before Europeans and developed a technology for printing more than 600 years before Europeans did. The invention and spread of papermaking and printing technologies have been a boon for human civilization. Antiquarian Chinese books, whether in the form of manuscripts, block-printed editions, or typeset books, have thus achieved a high level of artistry.

Like people, old books experience the vicissitudes of age. Most antiquarian Chinese book collections reveal deeply moving histories that frequently leave their examiners meditating upon the passage of time and sighing at life's fickleness. Thus, research into antiquarian Chinese book collections is not merely an academic task, but more an effective approach to understanding the mind and spirit of Chinese people and those who love Chinese culture. It is therefore a significant area of research.

Since the Portuguese first set foot on Macao in the early sixteenth century, the tiny region has gradually become a site of intercultural mingling. Macao has served as a locus of cultural exchange between China and the outside world, and as such has acquired a wide variety of culturalcharacteristics. Influential works have emerged throughout Macao's history, and many significant antiquarian books produced or collected in Macao remain hidden. The unique and diverse treasuretrove of Macao literature and book collections includes both Chinese and foreign-language documents. Chinese books do not only transmit Chinese culture but also play an important role incontributing to national self-identity and a sense of national unity. In this sense, Chinese documents and ancient book collections in Macao are cultural ties that link Macao to its motherland, mainland China. Moreover, Chinese documents from Macao act as a 
2 | Introduction to Antiquarian Chinese Book Collections in Contemporary Macao

powerful testimonial to the enduring Chinese cultural presence, demonstrating the symbiosis among heterogeneous cultures that emerged in Macao. Macao's antiquarian book collections reflect Macao's historical development and culture. They also evince Macao's impressive contribution to the preservation and transmission of humankind's cultural heritage-a contribution that cannot beignored.

The system adopted by Macao to categorize collections of antiquarian Chinese books is roughly similar to the traditional bibliographic divisions of the mainland. Book collections are divided into four basic categories: governmental public collections, academic collections in educational institutions, religious collections in churches or temples, and private collections (Tang 2009: 108117). At present, except for the initial work undertaken by the Ho Tung Library 河東圖書館 and the University of Macau Library 澳門大學圖書館，many antiquarian Chinese bookcollections in Macao have mostly remained unorganized and unknown to the public. This situationcalls for a comprehensive overhaul, as these historical treasures should be arranged, catalogued, and preserved.

There are two distinctive features of the antiquarian book collections in Macao. First, the Chinese phrase "antiquarian or ancient Chinese books" (Zhongwen guji 中文古籍) typically refersto woodblock-print books and manuscripts produced between the Tang dynasty (618-907) and the fall of the last imperial dynasty in 1911. These works tend to focus on various aspects of traditional Chinese culture. However, given Macao's special historical background, collections of ancient books in Macao include a wider range of books, both in terms of content and chronology.Antiquarian book collections in Macao sometimes include not only books from the imperial era, but also the thread-bound books of the Republican period (1912-1949). Secondly, in addition to Chinese-language books, many Macao collections (e.g., the Leal Senado Library 民政總署大樓圖書館 and the St. Joseph's Seminary Library 聖若瑟修院圖書館) hold a large number of preciousforeign-language books. While this article will occasionally touch on these foreign-language books, it is not within the scope of this article to offer a comprehensive investigation.

The three major categories of holdings of Macao's antiquarian Chinese book collections arethe rare books from the Ming and Qing dynasties, Macao local documents, and Western religious books. These books reflect different vantage points on the history and culture of Macao and are worthy of further investigation.

Since ancient times, Macao has been inhabited by Chinese people, and their culture is the dominant culture of the region. This culture can be divided into the "great tradition" and the "littletradition". "Little tradition" refers to the popular culture embodied in the people's daily lifestyle, customs, and habits, while "great tradition" refers to the elite culture of the upper class and intellectuals. Ancient Chinese elite culture is passed on through the study of traditional books suchas the Confucian classics, history, philosophy, and literature. This has always been the case in the mainland and has also always been the case in Macao.

Currently, traditional Chinese classics make up most of the value and variety of holdings inevery Macao library. This dominance is true not only of the famous libraries with a large number of collections such as the Ho Tung Library and the University of Macau Library. Even the library of Yuet Wah College 粵華中學圖書館, an institution founded by a Catholic group, keeps an 
almostcomplete initial set of the Complete Library in Four Sections (Sikuquanshu zhenben chuji 四庫全書珍本初集). This prevalence shows that Chinese culture is the common cultural foundation for the Chinese people of Macao. The story of the inter-generational success of, Zhao Yuanlu 趙元輅 (d.1780) and Zhao Yunjing 趙允菁 (1768-1834)，a father and son who passed the provincial civilexaminations during the reign of Emperor Qianlong (r. 1736-1796) and Emperor Jiaqing (r. 1795- 1821) in the Qing Dynasty, is often repeated, as is the story of Zheng Guanying 鄭觀應 (1842-1922), a scholar determined to bring people out of the pit of misery, and his book Shengshi weiyan 盛世危言(Chan 2020: 66-85).

The Macao people have always loved their country and their homeland and cherish not only its landscapes and history but also the local documents that record its history. At present, each library in Macao contains a certain amount of local books on Macao, including the local chronicles (e.g., Xiangshan xianzhi 香山縣誌 and Aomen jilue 澳門記略), the genealogies ofprominent families residing in Macao since early times such as Pujiang Zhaoshijiapu 浦江趙氏 家譜and Xingyang jiapu 焱陽家譜, the collected works written by scholars temporarily or permanentlyresiding in Macao such as Wanrugong zawen 宛如公雜文, Shengshi weiyan 盛世 危言, Luofu zhiheshanren shicao 羅浮侍鶴山人詩草, Aomen zashi澳門雜詩, and Liuchu ji六出集 , and all the teachingmaterials of children's learning compiled and printed by Chen Zibao 陳子襄 (1862-1922). Althoughthis is not an inclusive list of all the Chinese materials documenting the history of Macao, it sufficesto demonstrate the affection of the people of Macao for their local documents and their efforts to protect these treasures.

At the same time, as the Portuguese ruled Macao for over four hundred years, Western religions such as Catholicism have had a long presence in Macao. Consequently, there are many antiquarian Chinese books about Western culture (especially about Catholic culture) in Macao's libraries, a testament to Macao's role as a melting pot of Chinese and Western culture. St. Joseph's Seminary 聖若瑟修院 has a collection of precious antiquarian Western books, and the Leal SenadoLibrary 民政總署大樓圖書館, affiliated with the Central Library 中央圖書館 of Macao, holds more than 19,000 volumes of antiquarian Western books, Portuguese government documents, and Portuguese newspapers that date from the 17th century to mid-20th century. The successor to the Central Library of Macao, the Leal Senado Library first opened in 1929. The architectural design of the library is based on the Library of Mafra's Convent in Portugal (Biblioteca do Convento de Mafra), and the furniture and bookshelves are in the rococo style. The library focuses on collecting antiquarian books in foreign languages published before 1950, and currently contains over 10,000 volumes. It also collects some Portuguese documents about the Far East, and the decrees and government bulletins of all former Portuguese overseas territories from the sixteenth to the twentieth century. Furthermore, the collection holds over ninety kinds of Portuguese newspapers from the late nineteenth century to the early twentieth century, including Macao's first-ever newspaper, $A$ abelha da China.

Many of the books collected by St. Joseph's Seminary were originally from Macao's Chongshi School 崇實學校. The Chongshi School was founded in Macao in 1909 by Liang Yanming 梁 彥明(1885-1942), a member of the Tongmenghui 同盟會. The school enjoyed a fine reputation duringthe Republican period, although the school moved multiple times: to the Rua da Palha 賣草地街,Travessa dos Anjos 天神巷, Rua Central 龍高街, Avenida da Praia Grande 南灣街, and 
4 | Introduction to Antiquarian Chinese Book Collections in Contemporary Macao

Calçada deSanto Agostinho 巴掌斜巷， among other locations. When Mr Liang was murdered by a collaboratorfor political reasons, all the students were dismissed and the school was dissolved in 1961. St. Joseph's Seminary then purchased most of the ancient books in the Chongshi School library to protect them from destruction and has kept them ever since. This incident shows the mutual respect among the different cultures in Macao. Such tolerance and broad-mindedness are core cultural values of Macao.

Some of these libraries have a long and glorious history. For example, St. Joseph's Seminary, the Ho Tung Library Building, and the Leal Senado Library have been included in the United Nations' Directory of World Cultural Heritage. More importantly, the libraries usually have a longstanding historical relationship with the books they collect. For example, the Chinese Catholicbooks in St. Joseph's Seminary provide an opportunity for people to learn about the studies, the devotional activities, and the missionary work of students of the seminary since those seminarianshave selected and often read and used these books. Another example is the ancient manuscripts, paintings, calligraphy, and historical relics collected by the Kun Iam Temple 普濟禪院. Most ofthese materials relate to the activities of the temple and the Lingnan Chan sect with which the temple is affiliated. In a sense, this collection is essential for understanding the temple's history, the status of the temple in Macao, and the history of Lingnan Buddhism. Seen in this way, the organization and study of these ancient books is an essential part of discovering and enriching theculture of Macao.

For various reasons, it is difficult to grasp the full situation of private collections of antiquarian books in Macao. However, as some individual bibliophiles have generously donated their private collections to public libraries in recent years, some of these private collections have emerged into public view. Here are only a few noteworthy examples:

1. In 1982, Mr He Xian 何賢 (1908-1983) purchased a selection of books from the private collection of Wang Zhaoyong 汪兆鏞 (1861-1939) from Wang's son Wang Zongyan 汪宗衍, anddonated these books to the University of East Asia Library 東亞大學 圖書館, which is now a part ofthe University of Macao Library.

2. In 2002, Ms Liu Xianbing 劉羡冰 donated some of her private collection of antiquarian books to the Central Library of Macau, including about 100 volumes of translated textbooks, teaching materials, and new-style textbooks, dating from the Qing Dynasty to the present day.

3. Mr Wu Lixun 吳利勳 donated his private collections of antiquarian books, calligraphy, paintings, and historical relics of the Zhao family to the Macau Museum and the University of Macau Library;

4. After Mr Chen Weiheng 陳煒恒 (1962-2007) passed away, he left his entire private collection of ancient books to the University of Macau Library in his will.

Acting out of a sincere intention to preserve Chinese culture and tradition, these people and otherunnamed donors have made efforts to collect ancient books and unselfishly donate their collectionsto public institutions. Their generosity is a highlight of the history of book collecting in Macao. 
Laozi says, "An ascent of 100 paces begins beneath your foot" (Ryden 2008: 133). The investigation and study of Macao's antiquarian books have only just begun. Three main areas of research are worthy of future attention. First, building on current achievements, the study of Macao's antiquarian books will require an in-depth examination of the antiquarian books availableto the public, including their editions, collations, prefaces and postscripts, the situations in which they were circulated, and so on. We should not only focus on enhancing the protection of antiquarian books but also learn to utilize and develop these resources. Second, it is necessary to conduct a detailed survey of antiquarian book collections in those institutions that have not sharedinformation about their book collections with the public. Such a catalogue will provide a clearer andmore complete picture of the antiquarian book collections in Macao, as well as the opportunity to discover additional valuable antiquarian books. Third, the study of antiquarian books should emphasize the important implications of Macao's history and culture, and reveal Macao's great contributions to preserving Chinese culture and world heritage.

\section{Acknowledgment}

This article is based on the introduction and conclusion of Tang Chon Chit 鄧駿捷. Aomen gujicangshu 澳門古籍藏書 [Antiquarian book collections in Macao]. Hong Kong: Sanlian shudian;Macao: Aomen jijin hui, 2012, pp. 6-9 and pp. 95-100. I deeply appreciate the support of the MacaoFoundation and Hong Kong Sanlian Press.

\section{Declaration of Conflict of Interests}

The author(s) declared no potential conflicts of interest.

\section{Funding}

No funding has been received for the publication of this article. It is published free of any charge.

\section{References}

澳門中央圖書館（2002）・劉羡冰女士贈書目錄 [Macao Central Library. (2002). Catalogue of books presentedby Ms Liu Xianbing.]

Chan, Ying-Kit. (2020). "Heeding the warnings: Deng Huaxi and Zheng Guanying's Shengshi weiyan," Journal of Modern Chinese History 14, no.1: 66-85.

鄧駿捷（2009）・澳門各藏書系統漢文古籍的特色·文獻，(3)，108-117。[Tang, Chon Chit. (2009).

Characteristics of systems for the collection of antiquarian Chinese books in Macao. Wenxian, (3),108-117.]

Ryden, Edmund, trans. (2008). Daodejing / Laozi. Oxford: Oxford University Press. 